\title{
The difference between calcium ion levels in saliva before and after consuming red dragon fruit (Hylocereus polyrhizus)
}

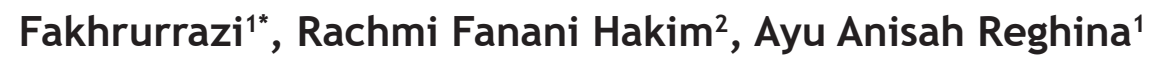 \\ ${ }^{1}$ Department of Oral and Maxillofacial Surgery, Faculty of Dentistry Syiah Kuala University, \\ Indonesia \\ ${ }^{2}$ Department of Oral Biology, Faculty of Dentistry Syiah Kuala University, Indonesia
}

\begin{abstract}
Introduction: Saliva is a complex oral fluid that is secreted by the major and minor salivary glands which have a vital role in sustaining oral hard and soft tissues. The calcium ion is one of the inorganic components of saliva, which plays a vital role in maintaining the tooth enamel integrity through the remineralisation process. The compliance of calcium intake for the body and the enhancement of calcium ions in saliva can be affected by consumption of fruits that comprise lots of calcium. Consumption of fruit containing high calcium can increase buffer capacity, support remineralisation and prevent demineralisation. One of the fruits with rich calcium is red dragon fruit (Hylocereus polyrhizus). The purpose of this study was to analyse the difference between the salivary calcium ion level before and after consumption of red dragon fruit (Hylocereus polyrhizus) on the students of Faculty of Dentistry Syiah Kuala University batch 2017. Methods: This study was pre-experimental with one group pretest-posttest design. The number of subjects in this study was 32 people with one group pretest-posttest design. Saliva was collected by spitting method five times. Results: The average salivary calcium ion before consumption of red dragon fruit (Hylocereus polyrhizus) was 1.972, and the average value of salivary calcium ion after consumption of red dragon fruit (Hylocereus polyrhizus) was 2.378. Results of the statistical test using the paired t-test showed a significant difference of the salivary calcium ion before and after consumption of red dragon fruit (Hylocereus polyrhizus) with the $p$-value $=0.001(p<0.05)$. Conclusion: There is a difference in the salivary calcium ion level before and after consumption of red dragon fruit (Hylocereus polyrhizus).
\end{abstract}

Keywords: Hylocereus polyrhizus, dragon fruit, calcium, saliva.

p-ISSN: 1979-0201; e-ISSN: 2549-6212; Available from: http://jurnal.unpad.ac.id/pjd/article/view/27087

DOI: 10.24198/pid.vol32no3.27087

Submission: Apr 27, 2020; Accepted: Oct 12, 2020; Published online: Nov 30, 2020

"Corresponding author: Fakhrurrazi, Department of Oral and Maxillofacial Surgery, Faculty of Dentistry Syiah Kuala University, Indonesia. Jalan Teuku Nyak Arief, Kopelma Darussalam, Banda Aceh, Aceh, Indonesia, 23111. Phone: +6281322510203; Email: abunidafahiza@gmail.com 


\section{INTRODUCTION}

Saliva is a complex oral fluid secreted by the major and minor salivary glands found in the oral mucosa. Around $90 \%$ saliva formed in the oral cavity is produced by the submandibular gland, the sublingual gland and parotid gland, the other $10 \%$ by other small salivary glands. The whole unstimulated saliva flow rate is approximately 0.3 $0.4 \mathrm{ml} / \mathrm{min} .{ }^{1}$ Saliva will help protect the teeth, tongue, oral mucous membrane, and oropharynx. ${ }^{2}$ Saliva secreted by the salivary gland consists of $99.5 \%$ water and $0.5 \%$ of other substances, in the form of organic and inorganic components. ${ }^{3}$ Organic components of saliva consist of protein, lipids, urea, amino acids, glucose, vitamins, and ammonia. ${ }^{4}$ The inorganic components of saliva consists of sodium, potassium, calcium, magnesium, chloride, sulfate, and phosphate. ${ }^{4}$

One of the electrolyte components in the saliva is calcium ion. ${ }^{4}$ Calcium is an inorganic component in saliva which plays an essential role in maintaining the integrity of tooth structure through the remineralisation process. Saliva can prevent the formation of early caries. Insufficient salivary calcium and phosphate ion will lead to the remineralisation process. ${ }^{2,4,5,6} \mathrm{Normal}$ calcium ion levels in the saliva are 1.2-2.8 mmol/L. ${ }^{7}$ Calcium needs can be obtained from fruits that contain lots of calcium. One of the fruits rich in calcium is red dragon fruit (Hylocereus polyrhizus).

One hundred grams of red dragon fruit contains as much as $8.5 \mathrm{mg}$ calcium. ${ }^{8}$ Calcium requirements for adults in the age group 19 to 50 years is $1000 \mathrm{mg}$ per day. ${ }^{9}$ An increase in the salivary calcium ion levels is influenced by the consumption of calcium-rich foods and beverages..$^{10}$ According to Yanti et al. ${ }^{11}$, there is an effect on eating cheddar cheese, which is one of the calcium-rich food, in increasing the salivary calcium ion concentration as an alternative to prevent dental caries. The high level of calcium found in red dragon fruit is proven to be able to strengthen bones, support tooth development, and support remineralisation process. ${ }^{12}$

Dragon fruit is a kind of cactus tree originating from Mexico, South America, and also Central America. Mexican residents call dragon fruit with name pitahaya or pitaya roja (red pitaya). ${ }^{8} \mathrm{At}$ present, dragon fruit has been widely cultivated in Vietnam, Taiwan, Malaysia, Australia, and Indonesia. ${ }^{8,12}$ There are four types of dragon fruit, namely white dragon fruit (Hylocereus undatus), red dragon fruit (Hylocereus polyrhizus), super red dragon fruit (Hylocereus costaricensis), and yellow dragon fruit (Selenicerius megalanthus). ${ }^{13}$

Purnama et al. ${ }^{14}$ conducted a study on the comparison of calcium levels in white dragon fruit (Hylocereus undatus) and red dragon fruit (Hylocereus polyrhizus) and discovered that calcium levels in red dragon fruit (Hylocereus polyrhizus) is higher ( $3.658 \mathrm{mg}$ in 100 grams) compared with white dragon fruit (Hylocereus undatus) (1.140 mg in 100 grams). The purpose of this study was to analyse the difference between the salivary calcium ion level before and after consumption of red dragon fruit (Hylocereus polyrhizus) on the students of Faculty of Dentistry Syiah Kuala University batch 2017.

\section{METHODS}

This study was pre-experimental with one group pretest-posttest design. This study was conducted in November 2018. All procedures were approved by the Research Ethics Board of the Faculty of Dentistry Syiah Kuala University prior to the study (number of ethical approval 071/KE/FKG/2018). The subject of this study was the students of Faculty of Dentistry Syiah Kuala University batch 2017. The sampling technique used was purposive sampling.

\section{Research subject selection}

The study was conducted for four days in November 2018. On the first day, subjects were collected. In general, for correlational research. The sampling technique used was purposive sampling based on inclusion and exclusion criteria to get the minimum number of samples, which obtained 32 subjects were needed to obtain good results. The subjects were given subject selection forms to obtain data on the subject's identity of the subject, including name, age, sex, and other statements needed, following the inclusion and exclusion criteria.

Inclusion criteria were as follows: students of Faculty of Dentistry Syiah Kuala University batch 2017; aged 18-19 years old; and willing to participate in the research by signing informed consent. Exclusion criteria were as follows: 
subjects with a history of systemic diseases associated with salivary glands such as Sjogren's syndrome and diabetes mellitus; subjects which were taken medications such as antidepressant, anticholinergic, antispasmodic, antihistamine, antihypertensive drugs (diuretics, a-adrenergic blockers, central a-adrenergic agonists), sedatives, and bronchodilators, which can affect the salivary flow rate; subjects with alcohol and narcotics consumption, and also smoking habit; subjects who are fasting when the research was conducted; subjects using orthodontic devices and prostheses; subjects which underwent head and neck radiation therapy; subjects with xerostomia.

Collection of saliva was performed before and after consumption of red dragon fruit (Hylocereus polyrhizus). Saliva collection was carried out on the second day at 09.00-11.00 WIT ${ }^{15,16,17}$ with the spitting method. Subjects were asked not to eat, drink, brush their teeth, and exercise for 1 hour before the study was conducted to avoid the possibility of salivary status alteration, which could affect the salivary calcium ions. Subjects were instructed to sit comfortably, with back upright, eyes opened, head lowered with one hand holding a saliva storage container, and not allowed to speak or swallowed. ${ }^{17,18}$ Before the consumption of red dragon fruit (Hylocereus polyrhizus), saliva was collected with the closedlip position. Furthermore, saliva was released into the saliva storage container every 1 minute for a total of 5 minutes. ${ }^{19}$

Researchers provided red dragon fruit (Hylocereus polyrhizus) consumed by subjects in this study. Dragon fruit was ripe and fresh, with a red colour both inside out. Dragon fruit was bloomed after two years from the beginning of planting. The time needed for dragon fruit from blooming to ripe, thus ready to be harvested around 30-35 days. ${ }^{20}$ All subjects were instructed to consume 100 grams of red dragon fruit within 5 minutes and given 5 minutes to rest.

Furthermore, saliva was re-collected after consumption of red dragon fruit (Hylocereus polyrhizus). All subjects were then instructed to remain silent for 1 minute, then every 1 minute for a total of 5 minutes, all subjects were asked to spit the saliva collected in the mouth into the saliva storage container. ${ }^{18,21}$ All saliva samples were stored in a cool box with a temperature of $4^{\circ} \mathrm{C}$ and taken to the Institute for Research and Standardization of Industry Banda Aceh, for the measurement of salivary calcium ions before and after consumption of red dragon fruit (Hylocereus polyrhizus) using an Atomic Absorption Spectrophotometer (AAS), then the results were recorded.

The salivary calcium ions were analysed in the Institute for Research and Standardization of Industry Banda Aceh using the Atomic Absorption Spectrophotometer (AAS) (Shimadzu AA 700). The AAS was used in analytical methods to determine the metal and metalloid elements, which measurements are based on light absorption with specific wavelengths by metal atoms in a state free; the results were then recorded. ${ }^{22}$

Saliva samples were prepared in advance for quantitative analysis of the salivary calcium ion with AAS. Preparation of saliva samples was carried out by using $1 \mathrm{ml}$ of saliva sample into a $50 \mathrm{ml}$ volumetric flask, $1 \mathrm{ml}$ of nitric acid $\left(\mathrm{HNO}_{3}\right.$ $\mathrm{HNO}_{3} 65 \% \mathrm{~b} / \mathrm{v}$ ), and the solution was diluted with distilled water to the limit mark. The sample solution was homogenised, and the absorbance was measured by AAS at $422.7 \mathrm{~nm} .{ }^{23}$

\section{Statistical analysis}

Data analysis was performed with SPSS software. Based on the normality test (Kolmogorov-Smirnov) results, the $p$-value $>0.05$, which indicated that the data was normally distributed. Then an analysis with paired t-test with a significance value of $p<0.05$ was conducted to see the difference in salivary calcium ion level before and after consumption of red dragon fruit (Hylocereus polyrhizus) on students of Faculty of Dentistry Syiah Kuala University batch 2017.

\section{RESULTS}

Normality test results in Table 1 shows that the $p$-value $>0.05$, which indicated that the data was normally distributed. The mean average of the salivary calcium ion level after red dragon fruit consumption was higher than before the consumption, which showed in Table 2. Table 3 presented the paired samples correlation test results, which indicated significant difference $(p=0.001)$ in the salivary calcium ion level before and after red dragon fruit consumption. 
The difference between calcium ion levels in saliva before and after consuming red dragon fruit (Fakhrurrazi et al.)

Table 1. Normality test result of salivary calcium ion level before and after consumption of red dragon fruit

\begin{tabular}{lcc}
\hline \multicolumn{1}{c}{ Salivary calcium ion level } & Mean \pm SD & p-value* \\
\hline Before consumption of red dragon fruit \pm SD & $1.9719 \pm 0.24787$ & 0.070 \\
\hline After consumption of red dragon fruit \pm SD & $2.3781 \pm 0.33767$ & 0.721 \\
\hline${ }^{*}$ Kolgomorov-Smirnov test & &
\end{tabular}

Table 2. Mean of the salivary calcium lon before and after consumption of red dragon fruit

\begin{tabular}{clc}
\hline Variable & \multicolumn{1}{c}{ Group } & Mean \pm SD \\
\hline \multirow{2}{*}{ Salivary calcium ion } & Before consumption of red dragon fruit & $1.972 \pm 0.248$ \\
& After consumption of red dragon fruit & $2.378 \pm 0.060$ \\
\hline
\end{tabular}

Table 3. Paired samples correlation results

\begin{tabular}{llcc}
\hline & $\mathrm{N}$ & Correlation & Sig. \\
\hline Salivary calcium ion before and after consumption of red dragon fruit & 32 & 0.675 & 0.001 \\
\hline
\end{tabular}

Table 4. Paired samples test results of salivary calcium ion level before and after consumption of red dragon fruit

\begin{tabular}{|c|c|c|c|}
\hline \multicolumn{2}{|c|}{ Average salivary calcium ion level } & \multirow{2}{*}{$\begin{array}{l}\text { Salivary calcium ion level before and after } \\
\text { consumption of red dragon fruit }\end{array}$} & \multirow[t]{2}{*}{ P-value } \\
\hline $\begin{array}{l}\text { Before consumption of red } \\
\text { dragon fruit } \pm \text { SD }\end{array}$ & $\begin{array}{l}\text { After consumption of red } \\
\text { dragon fruit } \pm \text { SD }\end{array}$ & & \\
\hline $1.972 \pm 0.248$ & $2.378 \pm 0.338$ & 0.406 & 0.001 \\
\hline
\end{tabular}

\section{DISCUSSION}

The current research results suggested that an average increase in the salivary calcium ion level before and after consumption of 100 grams of red dragon fruit (Hylocereus polyrhizus) was $0.406 \mathrm{Mmol} / \mathrm{L}$. This result indicated that the consumption of red dragon fruit (Hylocereus polyrhizus), which contains high calcium might increase the salivary calcium ion level, but still in the average level, which is 1.2-2.8 $\mathrm{Mmol} / \mathrm{L}^{7}$ Previous research conducted by Yanti et al. ${ }^{11}$, which investigated the effect of cheddar cheese consumption on the salivary calcium ion, showed that the salivary calcium ion could be increased into $0.67 \mathrm{Mmol} / \mathrm{L}$. Increase in the salivary calcium ion level after consumption of red dragon fruit (Hylocereus polyrhizus) occurs because calcium ions are dissolved during the mastication process.

Yanti et al. ${ }^{11}$ also suggested that consumption of cheddar cheese can also increase the salivary calcium ion. Calcium ion from consumed food may enter the acinar cells in the salivary glands, or accumulates in the gingival sulcus, which can flow and release the calcium ions into saliva. The calcium ion is one of the electrolyte components found in saliva and gingival crevicular fluid. ${ }^{24}$

The mechanism of salivary calcium ion increase begins during the mastication process, and the red dragon fruit (Hylocereus polyrhizus) is also ingested with saliva. Calcium is absorbed in the duodenum in the ionised form, and a transcellular transport occurs. Calcium ions in transcellular which transported into the membrane are mediated by epithelial calcium channels (CaT1), then the intracellular calcium is bound by calcium-binding proteins (calbindin) or absorbed into the endoplasmic reticulum by active calcium pump, sarco/endoplasmic reticulum $\mathrm{Ca}^{2+}$ (SERCA). Calcium secretion from cells is carried out by the primary active mechanism, which is the plasma calcium pump ATPase (PMCAs-1). ${ }^{25,26}$

The transcellular transport process occurs within 2-3 minutes. ${ }^{27,28}$ In the research conducted by Homann et al..$^{25}$, it is discovered the presence of CaT-Like, calbindin-2, SERCA-2, SERCA-3, and PMCAs in salivary gland acinar cells on immunohistochemical examination. Based on this finding, it is explained that calcium can enter acinar cells in the basolateral section by CaT-Like calcium channels. Intracellular calcium or calcium in the cytoplasm maintained a concentration of around $100 \mathrm{nM}$ and absorbed into the endoplasmic reticulum by SERCA-2 and SERCA-3, or binds to the calcium-binding protein, calbindin-2. Calcium is secreted into saliva by PMCAs. ${ }^{25}$ Calcium is one of the essential ions in saliva and must be maintained within normal limits. 
Calcium in the cells can be regulated at all times. Calcium obtained from the consumption of red dragon fruit (Hylocereus polyrhizus) enters into the cytoplasm of acinar cells and absorbed into the endoplasmic reticulum. New incoming calcium can increase the concentration of preexisting calcium ions in the cytoplasm. Pre-existing calcium ions are regulated by new calcium ions that enter after the consumption of red dragon fruit (Hylocereus polyrhizus) and activates the PMCAs by releasing the calcium ions from cells into saliva, to maintain the average concentration of calcium ions in the cytoplasm (100 nM) thus increasing the salivary calcium ion level. ${ }^{24}$

The red dragon fruit (Hylocereus polyrhizus) observed in this study had high water and calcium compositions. When the process of demineralisation or hydroxyapatite mineral salts dissolve from tooth enamel occurs after consuming carbohydrate, salivary $\mathrm{pH}$ can decrease due to acid production from bacteria. ${ }^{29}$ Calcium ion and salivary secretion will increase after consumption of red dragon fruit (Hylocereus polyrhizus), and cause an increase in the salivary buffer capacity, thus neutralise the acidic salivary $\mathrm{pH}$. The occurrence of the remineralisation process or the process of placing hydroxyapatite mineral salts back into the tooth enamel can prevent the formation of caries when supported with sufficient calcium ions. ${ }^{6,15}$ Consumption of 100 to 1000 grams of red dragon fruit (Hylocereus polyrhizus) contains $6.3-8.8 \mathrm{mg}$ calcium per 100 grams, which is enough to fulfil the calcium needs per day for adults. ${ }^{8,9}$

Based on the paired t-test results, the salivary calcium ion level before and after consumption of red dragon fruit (Hylocereus polyrhizus) suggested a significant difference with the $p$-value of $0.001 \quad(p<0.05)$. This result was consistent with the results of the research conducted by Yanti et al. ${ }^{11}$, which showed that consumption of cheddar cheese is effective in increasing the concentration of salivary calcium ions.

The study showed a significant increase in the concentration of salivary calcium ions before consumption of cheddar cheese $(1.67 \pm$ $0.44 \mu \mathrm{g} / \mathrm{ml}$ ) and 5 minutes after consumption of cheddar cheese $(2.34 \pm 0.89 \mu \mathrm{g} / \mathrm{ml}) .{ }^{11}$ The results of the current research proved that red dragon fruit (Hylocereus polyrhizus) was effective in increasing the salivary calcium ion level. Calcium ion contained in red dragon fruit (Hylocereus polyrhizus) can protect teeth from acid by increasing the salivary $\mathrm{pH}$, reducing the demineralisation process, and increasing the remineralisation process. ${ }^{6,12}$

\section{CONCLUSION}

There is a difference of the salivary calcium ion level before and after consumption of red dragon fruit (Hylocereus polyrhizus).

\section{REFERENCES}

1. Iorgulescu G. Saliva between normal and pathological. Important factors in determining systemic and oral health. J Med Life. 2009; 2(3): 303-7.

2. Porcheri C, Mitsiadis TA. Physiology, pathology and regeneration of salivary glands. Cells. 2019; 8(9): 976. DOI: 10.3390/cells8090976

3. Humphrey SP, Williamson RT. A review of saliva: Normal composition, flow and function. J Prosthet Dent. 2001; 85(2): 162-9. DOI: $10.1067 / \mathrm{mpr} .2001 .113778$

4. Indriana T. The relationship between salivary flow rate and calcium ion secretion in saliva. Stomatognatic J Ked Gi Unej. 2010; 7(2): 12931.

5. Flint PW, Haughey BH, Lund VJ, Niparko JK, Robbins KT, Thomas JR, et al. Cummings Otolaryngology - Head and Neck Surgery. $6^{\text {th }}$ ed. Philadelphia: Saunders-Elsevier; 2015. p. 1208.

6. De Almeida PDV, Grégio AMT, Machado MÂN, De Lima AAS, Azevedo LR. Saliva composition and functions: A comprehensive review. J Contemp Dent Pract. 2008; 9(3): 72-80. DOI: 10.5005/jcdp-9-3-72

7. Ramos-Casals M, Stone JH, Moutsopoulos HM. Sjogren's Syndrome: Diagnosis and Therapeutics. London: Springer-Verlag; 2012. p. 522.

8. Cheah LK, Eid AM, Aziz A, Ariffin FD, Elmahjoubi A, Elmarzugi NA. Phytochemical properties and health benefits of Hylocereusundatus. Nanomed Nanotechnol. 2016; 1(1): 1-10. DOI: 10.23880/NNOA-16000103 
9. Institute of Medicine (US) Committee to Review Dietary Reference Intakes for Vitamin $\mathrm{D}$ and Calcium; Ross AC, Taylor CL, Yaktine AL, Del Valle B, eds. Dietary Reference Intakes for Calcium and Vitamin D. Washington (DC): National Academies Press (US); 2011.

10. Lin HS, Lin JR, Hu SW, Kuo HC, Yang YH. Association of dietary calcium, phosphorus, and magnesium intake with caries status among school children. Kaohsiung J Med Sci. 2014; 30(4): 206-12. DOI: 10.1016/j. kjms.2013.12.002

11. Jenkins GN, Hargreaves JA. Effect of eating cheese on $\mathrm{Ca}$ and $\mathrm{P}$ concentrations of whole mouth saliva and plaque. Caries Res. 1989; 23(3): 159-64. DOI: 10.1159/000261170

12. Rathee M, Singla S. Tamrakar AK. Calcium and oral health: A review. Int J Sci Res. 2013; 2(9): 335-6. DOI: 10.15373/22778179/SEP2013/116

13. Genesiska G, Pratiwi H. Extract of dragon fruit pulp (Hylocereus polyrhizus) potentially stain chromosomes of red onion (Allium ascalonicum). Biogenesis. 2018; 6(2): 93-7. DOI: $10.24252 /$ bio.v6i2.4835

14. Zainoldin KH, Baba AS. The effect of Hylocereus polyrhizus and Hylocereus undatus on physicochemical, proteolysis, and antioxidant activity in yogurt. World Acad Sci Eng Tech. 2009; 60: 361-6.

15. Moore KL, Dalley AF, Agur AMR. Clinically Oriented Anatomy. $7^{\text {th }}$ ed. Philadelphia: Wolters Kluwer Health/Lippincott Williams \& Wilkins; 2013. p. 944.

16. Devi TJ. Saliva - A potential diagnostic tool. IOSR J Dent Med Sci. 2014; 13(2): 52-57.

17. Kaur M. A study of analytical indicators of saliva. Ann Ess Dent. 2012; 4(4): 9-18.

18. Navazesh M, Kumar SKS. Measuring salivary flow: Challenges and oppurtinities. J Am Dent Assoc. 2008; 139 Suppl: 35S-40S. DOI: 10.14219 /jada.archive. 2008.0353

19. Mori F, Hiraishi N, Otsuki M, Tagami J. Effect of mastication on flow and properties of saliva.
Asian Pac J Dent. 2012; 12: 1-5.

20. Perween T, Mandal KK, Hasan MA. Dragon fruit: An exotic super future fruit of India. J Pharmacogn Phytochem. 2018; 7(2): 10226.

21. Glick M. Burket's Oral Medicine. $12^{\text {th }}$ ed. North Carolina: PMPH USA; 2015. p. 212-51

22. Pohl $P$, Stecka H, Jamroz P. Fast and interference free determination of calcium and magnesium in honeys by solid phase extraction followed by flame atomic absorption spectrometry. J Braz Chem Soc. 2012; 23(4): 710-7. DOI: 10.1590/S0103-50532012000400017

23. Bai Y, Ouyang JM, Bai Y, Chen ML. Simultaneous determination of calcium and magnesium in urines by flame atomic absorption spectrometry. Guang Pu Xue Yu Guang Pu Fen Xi. 2004; 24(8): 1016-9.

24. Ambudkar IS. Regulation of calcium in salivary gland secretion. Crit Rev Oral Biol Med. 2000; 11(1): 4-25. DOI: 10.1177/10454411000110010301

25. Homann V, Kinne-Saffran E, Arnold WH, Gaengler P, Kinne RKH. Calcium transport in human salivary glands: A proposed model of calcium secretion into saliva. Histochem Cell Biol. 2006; 125(5): 583-91. DOI: $10.1007 /$ s00418-005-0100-2

26. Del Valle HB, Yaktine AL, Taylor CL, Ross AC, eds. Dietary Reference Intakes for Calcium and Vitamin D. Washington (DC): National Academies Press; 2011. p. 38-41.

27. Bronner F. Mechanisms of intestinal calcium absorption. J Cell Biochem. 2003; 88(2): 38793. DOI: $10.1002 / \mathrm{jcb} .10330$

28. Wongdee K, Charoenphandhu N. Vitamin D-enhanced duodenal calcium transport. Vitam Horm. 2015; 98: 407-40. DOI: 10.1016/ bs.vh.2014.12.010

29. Abou Neel EA, Aljabo A, Strange A, Ibrahim S, Coathup M, Young AM, et al. Demineralizationremineralization dynamics in teeth and bone. Int J Nanomedicine. 2016; 11: 4743-63. DOI: 10.2147/IJN.S107624 